\title{
MULTIPARAMETRIC DETECTION OF BACTERIAL CONTAMINATION BASED ON THE PHOTONIC CRYSTAL SURFACE MODE DETECTION
}

\author{
Petrova $\mathrm{IO}^{1}$, Konopsky VN², Sukhanova AV ${ }^{1}$, Nabiev $\operatorname{IR}^{1} \otimes$ \\ ${ }^{1}$ Laboratory of Nano-Bioengineering, National Research Nuclear University MEPhl (Moscow Engineering Physics Institute), Moscow \\ ${ }^{2}$ Laboratory of Spectroscopy of Condensed Matter, Institute for Spectroscopy, Russian Academy of Sciences, Troitsk
}

\begin{abstract}
Conventional techniques for food and water quality control and environmental monitoring in general have a number of drawbacks. Below we propose a label-free highly accurate analytical technique for multiplex detection of biomarkers based on the analysis of propagation of Bloch waves on the surface of a photonic crystal. The technique can be used to measure molecular and cell affinity interactions in real time by recording critical and excitation angles of the surface wave on the surface of a photonic crystal. Based on the analysis of photonic crystal surface modes, we elaborated a protocol for the detection of the exotoxin A of Pseudomonas aeruginosa and the heat-labile toxin LT of Escherichia coli. The protocol exploits detection of affinity interactions between antigens pumped through a microfluidic cell and detector antibodies conjugated to the chemically activated silica chip. The proposed technique is highly sensitive, cheap and less time-consuming in comparison with surface plasmon resonance.
\end{abstract}

Keywords: photonic crystals, surface modes, bacterial toxins, real-time detection

Funding: this work was part of the Federal Targeted Program The National system of Chemical and Biological Security of the Russian Federation (2015-2020) supported by the Ministry of Healthcare of the Russian Federation (State grant No. K-27-HИP/144-5 dated December 24, 2015).

Acknowledgement: the authors wish to thank Tkachuk AP, Head of the Department of Translational Biomedicine (Gamaleya Research Institute of Epidemiology and Microbiology) for rabbit antibodies against the heat-labile toxin LT.

$\triangle$ Correspondence should be addressed: Igor R. Nabiev

Kashirskoe shosse 31, Moscow, 115529; igor.nabiev@gmail.com

Received: 28.07.2018 Accepted: 20.08.2018

DOI: $10.24075 /$ brsmu.2018.047

\section{МНОГОПАРАМЕТРИЧЕСКАЯ ДЕТЕКЦИЯ БАКТЕРИАЛЬНОГО ОБСЕМЕНЕНИЯ С ПОМОЩЬЮ АНАЛИЗА ИЗМЕНЕНИЙ РАСПРОСТРАНЕНИЯ ПОВЕРХНОСТНЫХ ВОЛН В ФОТОННЫХ КРИСТАЛЛАХ}

\author{
И. О. Петрова ${ }^{1}$, В. Н. Конопский ${ }^{2}$ А. В. Суханова ${ }^{1}$, И. Р. Набиев ${ }^{\square}$
}

Лаборатория нано-биоинженерии, Национальный исследовательский ядерный университет «МИФИ» (Московский инженерно-физический институт), Москва

2 Лаборатория спектроскопии конденсированных сред, Институт спектроскопии РАН, Троицк

\begin{abstract}
Традиционные методы оценки качества продуктов питания, воды и других сред имеют ряд недостатков. Предлагается безметочный высокоточный аналитический метод многопараметрической детекции биомаркеров, основанный на анализе изменений параметров распространения поверхностных волн на поверхности фотонного кристалла (ПВФК). Метод позволяет проводить измерения молекулярных и клеточных аффинных взаимодействий в реальном времени путем независимой регистрации величин угла полного внутреннего отражения и угла возбуждения поверхностной волны на поверхности фотонного кристалла. На основании метода анализа ПВФК разработан протокол детекции экзотоксина А Pseudomonas aeruginosa и термолабильного токсина LT Escherichia coli. Протокол основан на детекции в реальном времени аффинного взаимодействия между антигенами, раствор которых прокачивается через микрофлюидную ячейку, и специфическими распознающими антителами, конъюгированными с химически активированной кремниевой подложкой каналов поверхности ФК. Показано, что метод ПВФК отличается более высокой чувствительностью, а также уменьшенным временем проведения анализа и сниженной материалозатратностью, по сравнению с методом поверхностного плазмонного резонанса.
\end{abstract}

Ключевые слова: фотонные кристаллы, поверхностные волны, бактериальные токсины, детекция в реальном времени

Финансирование: исследование поддержано Министерством здравоохранения Российской Федерации, в рамках Федеральной целевой программы «Национальная система химической и биологической безопасности Российской Федерации (2015-2020 годы)», государственный контракт № К-27НИР/144-5 от 24.12.2015 г.

Благодарности: авторы благодарны заведующему лабораторией трансляционной биомедицины ФГБУ «НИЦЭМ им. Н. Ф. Гамалеи» Минздрава России А. П. Ткачуку за предоставление кроличьих антител против термолабильного токсина LT.

$\triangle$ Для корреспонденции: Игорь Русаилович Набиев

Каширское шоссе, д. 31, г. Москва, 115529; igor.nabiev@gmail.com

Статья получена: 28.07.2018 Статья принята к печати: 20.08.2018

DOI: $10.24075 /$ vrgmu.2018.047

Detection of pathogenic bacteria and their toxins in liquid samples is a critical component of food and water quality control and the environmental monitoring in general. Polymerase chain reaction (PCR), a well-established technique for pathogen detection, is highly sensitive yet lengthy, reagent-consuming and labor-intensive. Besides, it cannot recognize bacterial metabolites, including protein toxins (primary pathogenicity determinants), and other specific proteins, such as prions, since it is aimed at detecting nucleic acids.

At present, detection of proteins (e.g., protein toxins) in liquid samples is done by classic analytical techniques. Conventional western blotting and enzyme-linked immunosorbent assays (ELISA) are relatively user-friendly and cost-effective but at the same time low-throughput and time-consuming. They are 
suitable for clinical diagnosis but require additional sample preparation involving the use of enzymatic and fluorescent labels to amplify the emitted signal, which increases costs and complicates the procedure.

Fortunately, novel techniques are emerging, including electrochemical immunoassays [1-2], chemiluminescence imaging [3], fluorescence flow immunoassays with activated silica beads [4], and electrochemical assays based on the use of affibodies [5]. Advantageously, all of them are multiplex, i.e. able to detect multiple analytes in one sample. Unlike traditional approaches, these techniques are high-throughput; however, they are expensive and the yielded results are difficult to interpret, which makes them unsuitable for routine use. The majority of these techniques rely on the use of additional labels, except for the label-free electrochemical assay, a sensitive and elegant approach, which, nevertheless, cannot be multiplexed [6].

Great promise is held by surface plasmon resonance [7] based on the excitation of surface plasmon polaritons at the metal/dielectric interface by incident light. This fast and sensitive label-free technique can go without complicated sample preparation. It exploits antibodies specific for a target protein that are conjugated to the surface of a thin gold film; soluble antigens present in the liquid sample bind to the antibodies, and the resulting mass transfer is manifested as a change in the refractive index value of the superficial layer of the liquid close to the surface of the golden film.

\section{Design of the experiment}

We propose a novel approach to the detection of bacterial contamination based on the use of photonic crystal surface modes (PCSMs). A photonic crystal is a structure in which the refractive index $(\mathrm{RI})$ is periodically modulated on the scale of a light wavelength. Such structures maintain the far-reaching longitudinal propagation of optical waves across the external surface. PCSMs are exploited in optical sensors [8-10]. PCSM-based sensors are reported to be more sensitive than those relying on surface plasmon resonance [9]. PCSMs allow detection of both parallel and perpendicular polarization of the light wave, meaning that the thickness of the surface layer and the refractive index of the liquid phase can be measured separately and a change in the reflected signal is indicative of a mass transfer event (interaction of a soluble analyte with a functionalized crystal surface) regardless of the refractive index shifts occurring in close proximity to this surface.

Advantageously, this approach allows easy recovery of a chip surface by plasma cleaning. The chip can be reactivated and conjugated to another detector protein. This means that the PC chip can be used an infinite number of times and activated in advance before the actual experiment.

In this work we studied the interaction between the polymer microbeads coated with a layer of a polyelectrolyte (negatively charged polyacrylic acid) and the surface of a PCSMbased sensor coated with positively charged poly(sodium 4-styrenesulfonate). Because of their size (4.08 $\mu \mathrm{m}$ in diameter), microbeads can represent a bacterial cell model. Given that, our work demonstrates the feasibility of bacterial cell detection in a liquid sample using a PCSM-based biosensor.

Besides we show that a PCSM-based biosensor can detect bacterial toxins in a liquid sample using the exotoxin A of Pseudomonas aeruginosa and the heat-labile toxin LT of Escherichia coli.

Below we describe the main stages in the development of the proposed analytical technique for the multiplex detection of biomarkers and its application for the detection of bacterial toxins.

\section{Preparation}

\section{Reagents}

The following reagents were used: sodium chloride, > 99\% (Sigma-Aldrich, S6191; USA); ethanol, 99.5\% (Acros Organics, AC615090010; Belgium); acetone for high-performance liquid chromatography, 99.8\% (Acros Organics, 268310010; Belgium); (3-aminopropyl)triethoxysilane (APTES), 99\% (SigmaAldrich, 440140; USA); glutaraldehyde, grade I, 25\% in $\mathrm{H}_{2} \mathrm{O}$ (Sigma-Aldrich, G5882; USA); sodium phosphate dibasic heptahydrate, 98-102\% (Sigma-Aldrich, S9390; USA); sodium phosphate monobasic monohydrate, $\geq 98 \%$ (Sigma-Aldrich, S9638; USA); phosphate buffered saline (PBS), tablets (SigmaAldrich, P4417; USA); protein A, United States Pharmacopeia (USP) Reference Standard (Sigma-Aldrich, 1578805; USA); poly(sodium 4-styrenesulfonate) (PSS), average Mw 70,000 (Sigma-Aldrich, 243051; USA); poly(allylamine hydrochloride) (PAH), average Mw 50,000 (Sigma-Aldrich, 283223; USA); poly(acrylic acid) (PAA), average $\mathrm{Mw} \sim 130,000$ (SigmaAldrich, 181293; USA); rabbit antibodies to the exotoxin A of Pseudomonas aeruginosa, whole antiserum (Sigma-Aldrich, P2318; USA); the exotoxin A of Pseudomonas aeruginosa, lyophilized powder (Sigma-Aldrich, P0184; USA); the heat-labile recombinant toxin LT of Escherichia coli, subunit B, > 90\%, lyophilized powder (Sigma-Aldrich, E8656; USA); crystalline bovine serum albumin (BSA), lyophilized powder, $\geq 98.0 \%$ (GE) (Sigma-Aldrich, 05470; USA).

The rabbit antibodies against the heat-labile toxin LT were courtesy of Tkachuk AP, Head of the Department of Translational Biomedicine, Gamaleya Research Institute of Epidemiology and Microbiology.

\section{A biosensor based on the detection of surface modes in a photonic crystal}

We used the PCSM-based biosensor EVA 2.0 described in [10] with the following one-dimensional PC structure: substrate/ $(\mathrm{LH})_{3} \mathrm{~L}$ '/water, where $\mathrm{L}$ is a $\mathrm{SiO}_{2}$ layer with thickness $d_{1}=186.4$ $\mathrm{nm}, \mathrm{H}$ is a $\mathrm{Ta}_{2} \mathrm{O}_{5}$ layer with thickness $d_{2}=115.2 \mathrm{~nm}$, and L' is a $\mathrm{SiO}_{2}$ layer with thickness $d_{3}=776.8 \mathrm{~nm}$.

The 7-layer structure with the starting and finishing layers made of $\mathrm{SiO}_{2}$ was created by magnetron sputtering. The prism and the glass plate were fabricated from BK-7 glass. Refractive indices of the substrate, $\mathrm{SiO}_{2}, \mathrm{Ta}_{2} \mathrm{O}_{5}$ and water at $\lambda=632.8$ $\mathrm{nm}$ were $n_{0}=1.515, n_{1}=n_{3}=1.47, n_{2}=2.07$, and $n_{\mathrm{e}}=1.332$, respectively.

The obtained data were processed in Origin 8.1 (OriginLab; USA).

\section{Microbeads}

Latex microbeads of $4.08 \mu \mathrm{m}$ in diameter (MF-COOH-AR421 Carboxyl-modified Melamine Resin-Research Particles, $10 \mathrm{ml}$ $10 \%$ w/v aq. suspension (microParticles $\mathrm{GmbH}$; Germany)) were coated with alternating layers of the oppositely charged polyelectrolytes $\mathrm{PAH}$ and PSS using the layer-by-layer deposition technique proposed in [11] following the pattern PAH/PSS/ $\mathrm{PAH} / \mathrm{PSS} / \mathrm{PAH}$; the coating was finished with a layer of PAA.

\section{Preparation of the photonic crystal silica chip for the experiment with microbeads}

Before the experiment, the silica PC chip was left in the UV cleaner box for at least $30 \mathrm{~min}$. 
The chip was mounted in the microfluidic flow cell for further measurements. To make the liquid flow through the cell, a peristaltic pump was used. After the flow cell was assembled, $1 \%$ aqueous APTES solution was pumped through it at $100 \mathrm{\mu l} / \mathrm{min}$ for $5 \mathrm{~min}$ to activate the surface of the PC by amino groups. Then $100 \mathrm{mg} / \mathrm{ml}$ solutions of PSS and PAH in $0.5 \mathrm{NaCl}$ were pumped through the flow cell successively for 5 min each. Before changing the solution, the flow cell was washed with $0.5 \mathrm{NaCl}$. To ensure even coating of the chip, three bilayers of $\mathrm{PSS} / \mathrm{PHH}$ were applied onto it in succession. After applying the finishing layer of $\mathrm{PAH}$, the medium was replaced with $100 \mathrm{mM}$ sodium phosphate buffer $(\mathrm{pH}$ 8.0) containing $0.5 \mathrm{M}$ $\mathrm{NaCl}$. The microbeads were suspended in the same buffer at a concentration of $10^{6}$ beads per $1 \mathrm{ml}$. The microbead suspension was pumped through the flow cell at $100 \mu \mathrm{l} / \mathrm{min}$ for $10 \mathrm{~min}$.

\section{Preparation of the photonic crystal silica chip for the experiments with proteins}

The PC chip was left in the UV cleaner box for 30 min to clean each side of the crystal and then washed once in acetone and once in ethanol successively followed by 3 washes in milliQ, with simultaneous exposure to UV light for 5 min. After that, the substrate was left to dry at $70^{\circ} \mathrm{C}$. The cleaned chip was incubated in 1\% APTES solution in acetone for $16 \mathrm{~h}$ to functionalize its surface by amino groups and then calcinated at $120{ }^{\circ} \mathrm{C}$ for $90 \mathrm{~min}$. Such aminized chips can be stored for at least one month without losing their properties. Before taking measurements, the chip was treated with $2.5 \%$ glutaraldehyde in the sodium-phosphate buffer $(\mathrm{pH} 7.4)$ under gentle stirring for $30 \mathrm{~min}$. Dextran or other polymer frameworks were not used for chip preparation.

The flow cell was attached to the prepared chip. The flow speed was $30 \mu \mathrm{l} / \mathrm{min}$. To functionalize the surface of the chip with detector antibodies, the solution of protein A $(50 \mu \mathrm{g} / \mathrm{ml})$ in PBS was pumped through the cell until the signal stabilized. Then the flow cell was washed in PBS for 2 min. After the monolayer of protein $A$ bound to the surface of the chip, the antibody solution $(50 \mu \mathrm{g} / \mathrm{ml})$ was pumped through the flow cell again until the signal was stable. Protein A present on the surface of the PC chip bound the Fc fragment of the immunoglobulin ensuring a uniform orientation pattern of bound antibodies. The surface regions that did not react with the protein were neutralized with $2 \%$ solution of bovine serum albumin (BSA) in PBS, and the flow cell was washed with PBS until the signal reached the plateau. Finally, the studied sample was pumped though the cell at $30 \mu \mathrm{l} / \mathrm{min}$

\section{Deposition of polyelectrolyte-coated microbeads on the chip coated with a layer of an oppositely charged polyelectrolyte}

Layer-by-layer deposition of polyelectrolytes on the APTESactivated chip surface caused a stepwise increase in the thickness of the superficial layer (Fig. 1A). Thickness values observed for the first PSS and PAH layers were lower than those observed for the subsequent layers, suggesting that two first layers of polyelectrolytes covered the surface incompletely.

The binding of PAA-coated microbeads to the surface of the crystal caused the superficial layer to slowly grow in thickness. This phenomenon was not observed if the buffer solution pumped through the flow cell did not contain microbeads.

Notably, the kinetics of microbead binding was linear $\left(R^{2}=0.996\right)$ and not dose dependent (Fig. 1B), possibly due to a low concentration of microbeads unable to saturate the chip surface (the area of the chip surface in contact with the solution was $1 \mathrm{~cm}^{2}$, as determined by the flow cell architecture). The area on the chip surface occupied by one microbead did not exceed $13 \mu \mathrm{m}^{2}$, i.e. to fully cover the surface one would need $\sim 10^{7}$ microbeads. Therefore, the thickness of the microbead monolayer could be expected to be equal to the diameter of the microbead, i.e. $4.08 \mu \mathrm{m}$. Accordingly, the binding of $10^{6}$ microbeads would correspond to a $400 \mathrm{~nm}$ thickness of the superficial layer. However, at low thickness values we can only measure the optical depth of a layer, that is its physical thickness multiplied by the refractive index. By taking the refractive index equal to 1.56 [10], we get the expected thickness of $624 \mathrm{~nm}$ consistent with the observed thickness. Knowing the flow rate, the rate of superficial thickness growth and the concentration of microbeads, we can estimate the number of the bound microbeads. As the microbeads are pumped through the cell for $10 \mathrm{~min}$, the superficial layer increases in thickness by $0.57 \mathrm{~nm}$, meaning that $1 \times 10^{3}$ microbeads $(0.1 \%$ of the total number of pumped microbeads) have been bound.

\section{Detection of bacterial toxins}

To attempt detection of protein toxins in a solution using the PCSW-based biosensor, we selected two toxins: the exotoxin of Pseudomonas aeruginosa and the heat-labile toxin of Escherichia coli.

Pseudomonas aeruginosa is a gram-negative motile rodshaped bacterium sized $1-5 \mu \mathrm{m}$ by $0.5-1 \mu \mathrm{m}$. It inhabits water and soil and causes opportunistic and nosocomial infections in humans. The exotoxin A of the bacteria consists of three domains: binding, transport and catalytic. Its cytotoxic activity is determined by the catalytic domain that inhibits synthesis of proteins by ATP-ribosylation of the elongation factor EF-2 [12-13]. Detection of this exotoxin is an important diagnostic problem normally solved by PCR which identifies the gene coding for it [14], ELISA which detects the presence of this toxin and a few other analytical techniques.

Escherichia coli is a gram-negative rod-shaped bacterium colonizing the lower intestinal tract of warm-blooded organisms. Enterotoxigenic strains of Escherichia coli can cause diarrhea by producing toxins such as the heat labile LT toxin. The latter consists of two subunits: the catalytically active subunit $A$ and the subunit B responsible for the binding to the cell [15]. LT expression stimulates secretion and facilitates the binding of the bacteria to epithelial cells [16].

For toxin detection, we developed a system consisting of flow cells with 1,2 or 4 channels. Briefly, the glass chamber with 1, 2 or 4 grooves is connected to a chemically activated sensitive surface of the silica chip functionalized with detector molecules. The amplitude of the signal recorded during antigen-antibody interactions on the sensor surface is directly proportional to the number of binding sites on the surface. The surface regions that have not reacted with the antigen are coated with BSA to avoid emission of a nonspecific signal.

If a cell has 2 or 4 channels, 1 of them can be used as a negative control; its surface is coated with BSA instead of antibodies.

In the experiment, the $50 \mu \mathrm{g} / \mathrm{ml}$ solution of the exotoxin A of Pseudomonas aeruginosa in PBS was pumped through the flow cell at $100 \mu \mathrm{l} / \mathrm{min}$ (Fig. 2). The obtained curve was similar to the SPR sensorgram and followed the same pattern of kinetics [17]. The binding of the protein to the sensor surface 
caused a rapid increase in the thickness of the superficial layer, which reaches the plateau quite soon. The plateau represents the equilibrium between the absorption and desorption rates. The kinetic curve can be approximated using the Langmuir absorption model. It has been theorized that the detection limit allowed by PCSM is $70 \mathrm{fg} / \mathrm{mm}^{2}$ of the studied sensor surface, which is well above the sensitivity of surface plasmon resonance [18]. But in practice, the lowest detectable concentration of exotoxin $A$ in our experiment was $30 \mu \mathrm{g} / \mathrm{ml}$, in spite of the low levels of the background noise. The sensorgram recorded during the detection of the heat-labile toxin LT (50 $\mu \mathrm{g} / \mathrm{ml}$ in PBS) demonstrated that the detection limit was $10 \mu \mathrm{g} / \mathrm{ml}$ (Fig. 3).

Of note, in the experiment we used whole antiserum. The use of affinity purified antibodies will definitely improve the sensitivity of the biosensor allowing it to reach the anticipated value [18], which is way higher than the sensitivity of surface plasmon resonance.

\section{A}

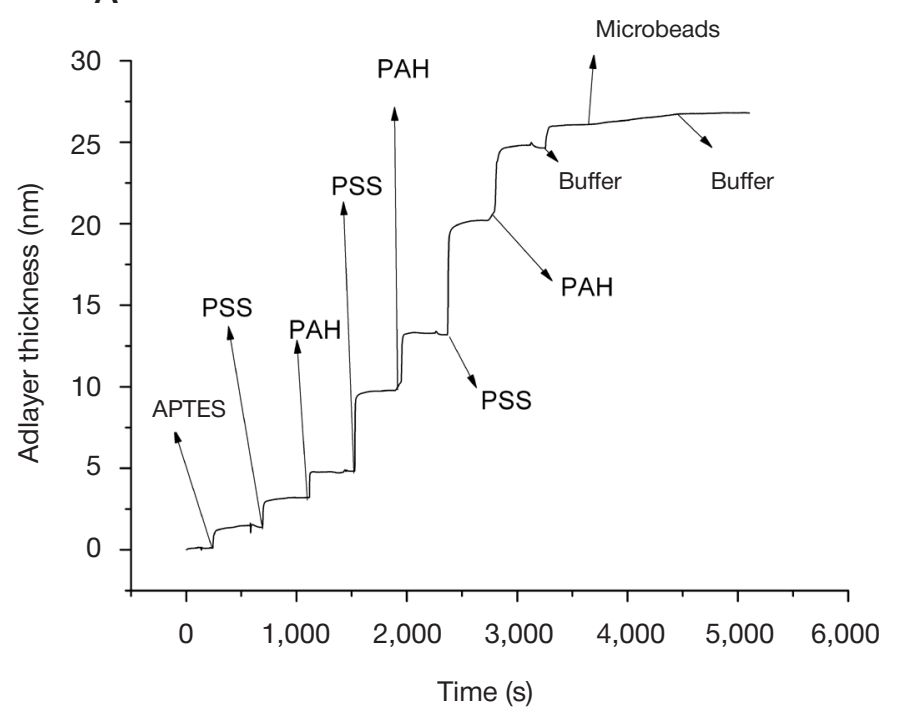

\section{Kinetics of bacterial cell binding to the surface of the sensor functionalized with antibodies}

The upper limit of the binding rate for the microbeads was calculated using the Smoluchowski-Levich equation [19] and was 3.46 particles $/ \mathrm{cm}^{2}$; the working surface of the sensor was $1 \mathrm{~cm}^{2}$, so the calculated value meant that 2,000 particles would be bound within 10 min. Here we can conclude that the binding rate of polyelectrolyte-coated microbeads to the surface of the biosensor coated with the oppositely charged polyelectrolyte in our system was close to the highest possible rate. Perhaps, it did not reach its maximum because the binding of microbeads to the surface is not instant and under real life conditions is determined not only by the diffusion of microparticles but also by their interaction with the surface. Therefore, we assume that the kinetics of bacterial cell binding to the sensor surface functionalized by antibodies

B

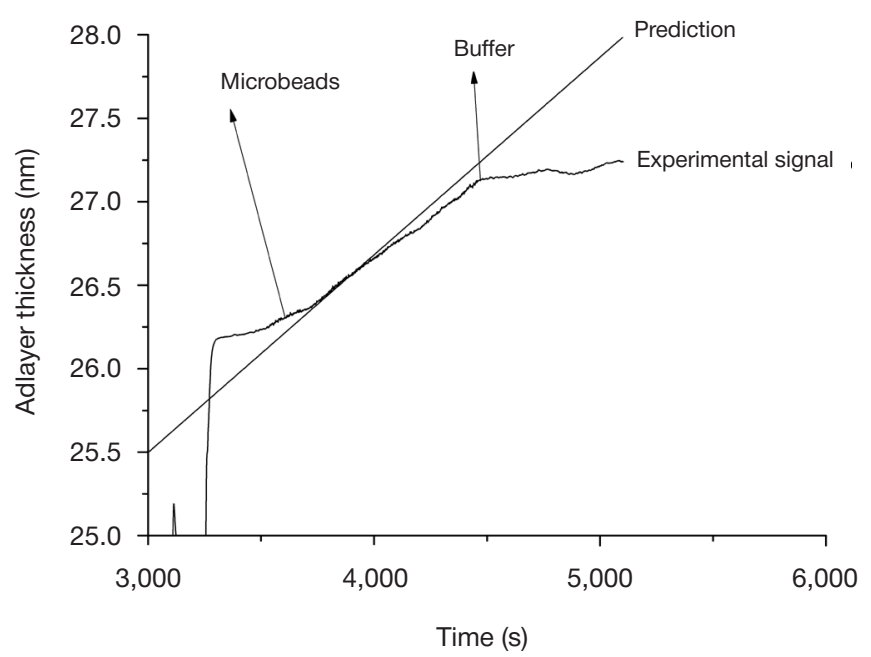

Fig. 1. Changes in the thickness of the superficial layer of the photonic crystal-based biosensor at the successive stages of surface preparation and the experiment studying the interaction between the polyelectrolyte-coated microbeads and the photonic crystal chip coated with an oppositely charged polyelectrolyte. Figure A shows how the adlayer on the surface of the photonic crystal changed in thickness when the crystal was treated with amino groups (APTES) and subjected to the deposition of layers of oppositely charged polyelectrolytes poly(sodium 4-styrenesulfonate) (PSS) and poly(allylamine hydrochloride) (PAH). The thickness of the surface increased with every applied layer of polyelectrolytes. The effect of the sodium phosphate buffer ( $\mathrm{pH} 8.0$ ) containing $0.5 \mathrm{M}$ NaCl pumped through the microfluidic cell is marked with a "Buffer» arrow. The microbeads used as a bacterial model were resuspended in the same buffer; the effect of the microbead suspension pumped through the microfluidic cell is marked with a «Microbeads» arrow. Figure $\mathbf{B}$ shows how the thickness of the photonic crystal surface increased as the suspension of microbeads coated with poly(acrylic) acid (PAA) was pumped through the cell. The «Buffer» arrow represents a point at which the suspension of the microbeads was discontinued and the buffer was supplied to the flow cell. The figure also shows the results of theoretical modelling of microbeads binding to the surface of the photonic crystal (see the article)

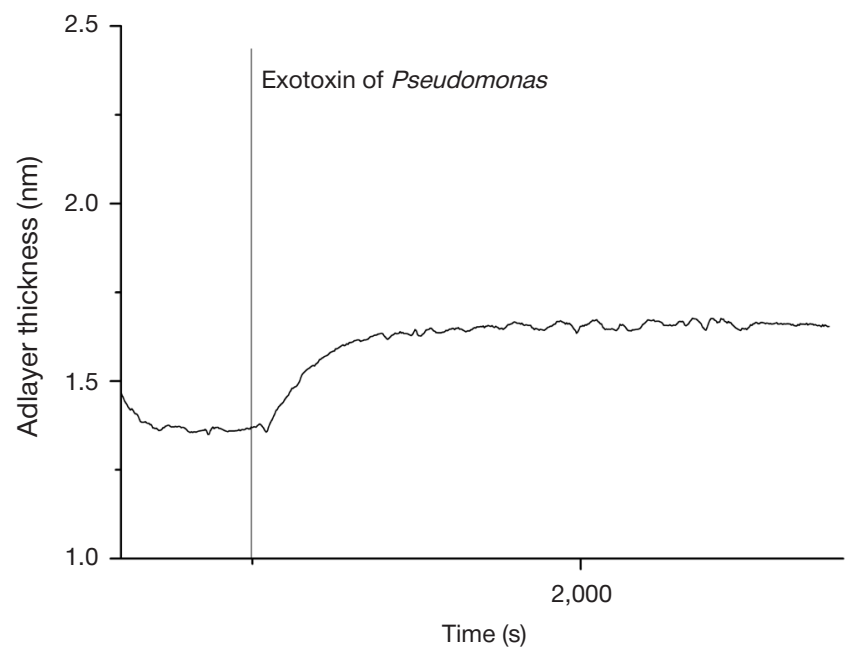

Fig. 2. Detection of the exotoxin A of Pseudomonas aeruginosa by the biosensor based on the photonic crystal surface mode detection

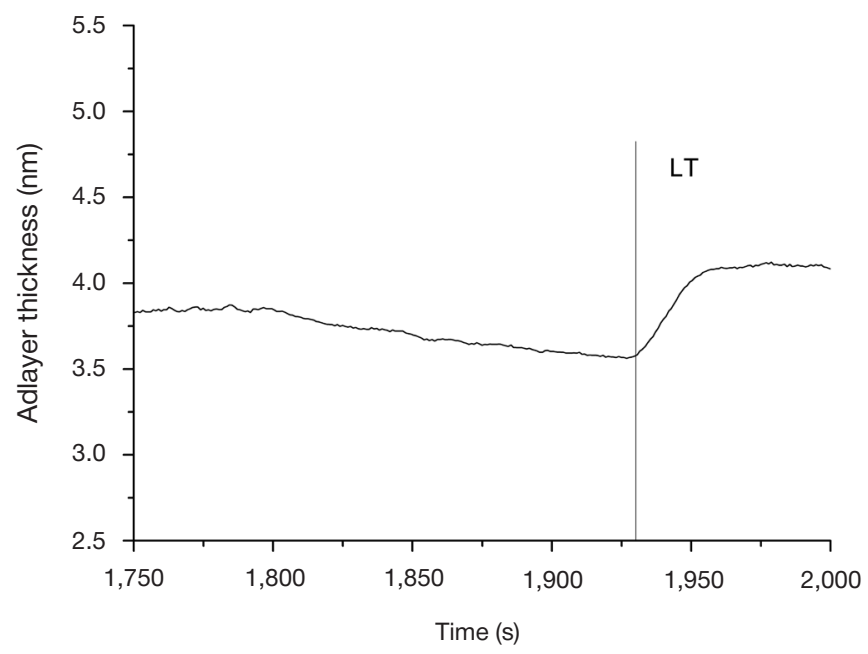

Fig. 3. Detection of the heat-labile toxin LT of Escherichia coli by the biosensor based on the photonic crystal surface mode detection 
can differ from that demonstrated in our experiment involving microbeads.

It should be noted that changes in the composition of the microbeads-containing solution affected the binding kinetics only insignificantly.

\section{Optimization of detection of bacterial toxins}

The results obtained in the experiment demonstrate the feasibility of multiplex detection of bacterial toxins using a PCSM-based biosensor. The detection limit can be lowered by (1) the use of affinity purified antibodies to the studied toxins; the antibody-antigen affinity is crucial because each molecule lacking it negatively affects the effective area of the sensor surface; (2) changing the parameters of the measuring flow cell [20]; (3) enhancing the signal by gold nanoparticles: the intensity of the signal from the crystal depends on mass transfer, so the use of specific antibodies recognizing a sterically distant epitope of the target protein and conjugated to colloid gold will increase the signal intensity at the same concentration of an analyte [21-22].

\section{CONCLUSIONS}

This work demonstrates the feasibility of PCSM-based detection of microparticles similar to bacterial cells in terms of their size in a liquid sample. We hope that the obtained results will assist development of protocols for real-time detection of bacteria in flow cells. The proposed technique is suitable for multiplex detection of protein toxins: the exotoxin A of Pseudomonas aeruginosa and the heat-labile toxin LT of Escherichia coli. Our findings could be used to design rapid and cheap tools for measuring bacterial contamination of water and food and establishing fast and accurate diagnosis of bacterial infections by detecting bacterial cells and their metabolites in the samples of biological fluids.

\section{References}

1. Wilson MS. Electrochemical Immunosensors for the Simultaneous Detection of Two Tumor Markers. Anal Chem. 2005; 77 (5): 14961502.

2. Xu T, Jia X, Chen X, Ma Z. Simultaneous electrochemical detection of multiple tumor markers using metal ions tagged immunocolloidal gold. Biosens Bioelectron. 2014; (56): 174-9.

3. Zong C, Wu J, Wang C, Ju H, Yan F. Chemiluminescence Imaging Immunoassay of Multiple Tumor Markers for Cancer Screening. Anal Chem. 2012; 84 (5): 2410-15.

4. Zhao Y, Zhao X, Pei X, et al. Multiplex detection of tumor markers with photonic suspension array. Anal Chim Acta. 2009; 633 (1): 103-8.

5. Ravalli A, Gomes C, Yamanaka H, Marrazza G. A label-free electrochemical affisensor for cancer marker detection : The case of HER2. Bioelectrochemistry. 2015; 106 (Pt B): 268-75.

6. Gomes RS, Moreira FTC, Fernandes R, Sales MGF. Sensing CA 15-3 in point-of-care by electropolymerizing O-phenylenediamine ( oPDA) on Au-screen printed electrodes. PLoS One. 2018; 13(5): [about 1 p.]. Available from: http://journals.plos.org/plosone/ article?id=10.1371/journal.pone. 0196656

7. Nguyen HH, Park J, Kang S, Kim M. Surface Plasmon Resonance: A Versatile Technique for Biosensor Applications. Sensors (Switzerland). 2015; 15 (5): 10481-510.

8. Michelotti F, Sciacca B, Dominici L, Quaglio M. Fast optical vapour sensing by Bloch surface waves on porous silicon membranes. Phys Chem Chem Phys. 2010; (12): 502-6.

9. Khan MU, Corbett B. Bloch surface wave structures for high sensitivity detection and compact waveguiding. Sci Technol Adv Mater. 2016; 17 (1): 398-409

10. Konopsky V, Karakouz T, Alieva E, Vicario C, Sekatskii S, Dietler G. Photonic Crystal Biosensor Based on Optical Surface Waves. Sensors. 2013; 13 (3): 2566-78.

11. Bilan RS, Krivenkov VA, Berestovoy MA, et al. Engineering of Optically Encoded Microbeads with FRET-Free Spatially Separated Quantum-Dot Layers for Multiplexed Assays. Chem Phys Chem. 2017; 18 (8): 970-9.

12. Toren P, Ozgur E, Bayindir M. Label-Free Optical Biodetection of Pathogen Virulence Factors in Complex Media Using Microtoroids

\section{Литература}

1. Wilson MS. Electrochemical Immunosensors for the Simultaneous Detection of Two Tumor Markers. Anal Chem. 2005; 77 (5): 14961502

2. Xu T, Jia X, Chen X, Ma Z. Simultaneous electrochemical detection of multiple tumor markers using metal ions tagged

immunocolloidal gold. Biosens Bioelectron. 2014; (56): 174-9.

3. Zong C, Wu J, Wang C, Ju H, Yan F. Chemiluminescence Imaging Immunoassay of Multiple Tumor Markers for Cancer Screening. Anal Chem. 2012; 84 (5): 2410-15.

4. Zhao Y, Zhao X, Pei X, et al. Multiplex detection of tumor markers 
with photonic suspension array. Anal Chim Acta. 2009; 633 (1): 103-8.

5. Ravalli A, Gomes C, Yamanaka H, Marrazza G. A label-free electrochemical affisensor for cancer marker detection : The case of HER2. Bioelectrochemistry. 2015; 106 (Pt B): 268-75.

6. Gomes RS, Moreira FTC, Fernandes R, Sales MGF. Sensing CA $15-3$ in point-of-care by electropolymerizing O-phenylenediamine ( oPDA ) on Au-screen printed electrodes. PLoS One. 2018; 13(5): [about 1 p.]. Available from: http://journals.plos.org/plosone/ article?id=10.1371/journal.pone.0196656

7. Nguyen HH, Park J, Kang S, Kim M. Surface Plasmon Resonance: A Versatile Technique for Biosensor Applications. Sensors (Switzerland). 2015; 15 (5): 10481-510.

8. Michelotti F, Sciacca B, Dominici L, Quaglio M. Fast optical vapour sensing by Bloch surface waves on porous silicon membranes. Phys Chem Chem Phys. 2010; (12): 502-6.

9. Khan MU, Corbett B. Bloch surface wave structures for high sensitivity detection and compact waveguiding. Sci Technol Adv Mater. 2016; 17 (1): 398-409

10. Konopsky V, Karakouz T, Alieva E, Vicario C, Sekatskii S, Dietler G. Photonic Crystal Biosensor Based on Optical Surface Waves. Sensors. 2013; 13 (3): 2566-78.

11. Bilan RS, Krivenkov VA, Berestovoy MA, et al. Engineering of Optically Encoded Microbeads with FRET-Free Spatially Separated Quantum-Dot Layers for Multiplexed Assays. Chem Phys Chem. 2017; 18 (8): 970-9.

12. Toren P, Ozgur E, Bayindir M. Label-Free Optical Biodetection of Pathogen Virulence Factors in Complex Media Using Microtoroids with Multifunctional Surface Functionality. ACS Sensors. 2018; 3 (2): 352-9.

13. Iglewski $\mathrm{BH}$, Liu PV, Kabat D. Mechanism of Action of Pseudomonas aeruginosa Exotoxin A: Adenosine DiphosphateRibosylation of Mammalian Elongation Factor 2 In Vitro and In Vivo. 1977; 15 (1): 138-44.
14. Khan AA, Cerniglia CE. Detection of Pseudomonas aeruginosa from clinical and environmental samples by amplification of the exotoxin A gene using PCR. Appl Environ Microbiol. 1994; 60 (10): 3739-45.

15. Norton EB, Branco LM, Clements JD. Evaluating the A-Subunit of the Heat-Labile Toxin (LT) As an Immunogen and a Protective Antigen Against Enterotoxigenic Escherichia coli (ETEC). PLoS One. 2015; 10 (8): [about 1 p.]. Available from: https://www.ncbi. nlm.nih.gov/pmc/articles/PMC4549283/

16. Allen KP, Randolph MM, Fleckenstein JM. Importance of HeatLabile Enterotoxin in Colonization of the Adult Mouse Small Intestine by Human Enterotoxigenic Escherichia coli Strains. Infect Immun. 2006; 74 (2): 869-75.

17. Schasfoort RBM, Tudos AJ, editors. Handbook of Surface Plasmon Resonance. Лондон: RSC Publisher; 2013. 524 c.

18. pcbiosensors.com [Internet]. Troitsk: PCbiosensors company. 2013 - [cited July 18, 2018.]. Available at: http://pcbiosensors. com/technology/technology.htm.

19. Myszka DG, HeX, Dembo M, Morton TA, Goldstein B. Extending the Range of Rate Constants Available from BIACORE : Interpreting Mass Transport-Influenced Binding Data. Biophysical Journal. 1998; 75 (August): 583-94.

20. Lynn NS, Homola J. Biosensor Enhancement Using Grooved Micromixers: Part I, Numerical Studies. Anal Chem. 2015; 87 (11): 5524-30.

21. Springer T, Homola J. Biofunctionalized gold nanoparticles for SPR-biosensor-based detection of CEA in blood plasma. Anal Bioanal Chem. 2012; 404 (10): 2869-75.

22. Lee J, Cho H, Choi HK, Lee J-Y, Choi J-W. Application of Gold Nanoparticle to Plasmonic Biosensors. Int J Mol Sci. 2018; 19 (7): [about 14 p.]. Available from: http://www.mdpi.com/1422$0067 / 19 / 7 / 2021$ 